\title{
一般口演 2
}

\section{睡眠時ブラキシズムに対するプロトンポンプ阻害剂の治療効果の検討： プラセボ対照二重盲検クロスオーバー比較試験}

\author{
Evaluation of therapeutic efficacy of proton pump inhibitor for sleep bruxism: \\ a randomized, double-blind, placebo-controlled, crossover study \\ ○兼松恭子 ${ }^{1)}$, 大牟禮治人 ${ }^{1)}$, 永山邦宏 ${ }^{1)}$, 沼田政嗣 ${ }^{2)}$, 宮脇正一 ${ }^{1)}$ \\ $\bigcirc$ K. Kanematsu ${ }^{1)}$, H. Omure ${ }^{1)}$, K. Nagayama ${ }^{1)}$, M. Numata ${ }^{2)}$, S. Miyawaki ${ }^{1)}$ \\ 1) 鹿児島大学大学院医歯学総合研究科歯科矯正学分野 \\ 2) 鹿児島大学医学部・歯学部附属病院光学医療診療部 \\ ${ }^{1)}$ Department of Orthodontics, Kagoshima University Graduate School of Medical and Dental Sciences \\ ${ }^{2)}$ Division of Endoscopy, Kagoshima University Medical and Dental Hospital
}

\section{I. 目的}

睡眠時ブラキシズム (sleep bruxism : SB) は睡眠中 に上下の歯を無意識にこすり合わせたり，くいしばっ たりする習癖で, 睡眠障害の国際分類（ICSD-2）では 単純反復性運動障害に分類される.SB は歯の咬耗や破 折および顎関節症等の様々な問題を引き起こすが, 効 果が立証された治療法はまだ無い ${ }^{1)}$ 。一方, 胃食道逆 流（gastro-esophageal reflux：GER）は下部食道括約筋 の弛緩によって胃酸を含む胃内容物が食道内へ逆流す る現象で胸焼けや吞酸などの症状を引き起こす上部消 化管では最も一般的な疾患のひとつである ${ }^{2)}$. 我々はこ れまでSB と GER との関係に着目して研究を進め, 夜 間の GER に続いて閉口筋の筋活動が上昇し律動的な 咀 嚼筋活動 (rhythmic masticatory muscle activity： RMMA)が生じることや ${ }^{3)}$, 実験的な食道内酸刺激によっ てSBが誘発されることを明らかにしだ $。$ また, 最近 になり胃食道逆流症（gastro-esophageal reflux disease： GERD）の患者ではSB が高頻度に認められると報告さ れている ${ }^{5)}$.

GERD の診断および治療にはプロトンポンプ阻害薬 (proton pump inhibitor: PPI) が広く用いられている2). PPI は胃の壁細胞に存在するプロトンポンプに作用して 胃酸の分泌を強力に抑制するため, SB 患者においても 治療効果が期待されるが, その治療効果を検討した報告 はこれまでない. 本研究の目的は最も優れた研究デザイ ンであるプラセボ対照二重盲検比較試験で SB に対する
PPI の治療効果を検討することである.

\section{II. 方 法}

対象は一般公募で募集した歯ぎしりの自覚があるも のから，睡眠ポリグラフ検査（以下 PSG 検査）を行い 研究用診断基準 ${ }^{1)}$ で診断された 18 歳から 49 歳までの SB 患者 12 名とし，二次性ブラキシズムの疑いがある場合 や3 か月以内に服薬既往のあるものは対象から除外した (図)。すべての被験者は割付前に FSSG 問診票による消 化器症状の評価と内視鏡検査による上部消化管の精査を 行った.

薬剂はラベプラゾールナトリウム $10 \mathrm{mg} /$ 日（パリ エット ${ }^{\circledR}$ 錠 $10 \mathrm{mg}$ ，エーザイ，東京，以下 PPI 群）また はプラセボ（以下プラセボ群）を用い，1日1回夕食前 に 5 日間経口投与した。投薬の順序はランダムに決定し， ウォッシュアウト期間は 2 週間以上としてクロスオー バー試験を行った。投薬開始から 4 日目 (1st night) お よび 5 日目 (2nd night) の夜に咬筋筋電図や上半身の ビデオ撮影を含むPSG 検査を行った.

PSG 検査の結果から咬筋筋電図のバース卜頻度およ び総活動量, $\mathrm{SB}$ エピソードの頻度を求めた。各種睡眠 パラメーターの解析は専門技師が行った．PPIのSBに 対する治療効果を検討するため, PPI 群とプラセボ群と の間で統計学的に比較を行った。統計解析にはデータの 分布に応じて $t$ 検定もしくは Wilcoxon 検定を用いた。 


\section{III. 結果及び考察}

歯ぎしりの自覚があるものを一般公募したところ 95 名の応募があり，組入基準を満たし簡易検查で SB の兆 候が認められた 24 名に対して PSG 検査と内視鏡検査を 行い, PSG 検査の結果研究用診断基準を満たした 12 名 （男性 7 名，女性 5 名，平均年齢 30.3 歳）に対して割り 付けを行った（図). 術前の消化器症状は FSSG の平均 スコアが 7.9 点で, 消化器症状から GERD と診断される 10 点以上のスコアを示すものが 4 名認められた。内視 鏡検査で gradeM 以上の逆流性食道炎と診断されたもの が 12 名中 9 名で，そのうち 1 名はバレット上皮を認め た。また，胃食道逆流と関連する解剖学的形態である食 道裂孔ヘルニアが 2 名に認められた。

PPI の治療効果については, PPI 群はプラセボ群に比 ベて, 1st nightでは咬筋の筋電図バーストの頻度や総 活動量が有意に小さな值を示し（表 1)，2nd nightでは 咬筋の筋電図バーストの頻度や RMMA の頻度が有意に 小さな值を示し (表 2 ), 総じてPPI 投与によって咬筋 の筋活動や RMMA は減少する傾向が認められた。睡眠 関連の項目について 2 群間で有意な差は認められなかっ た。 今後, 治療効果の個人差や再現性, 長期間与薬によ る変化などついて更なる検討が必要であるが，本研究の 結果から, PPI はSB に対して統計学的に有意な治療効 果を示すことが示唆された。

\section{N. 文献}

1 ) Lavigne GJ, Manzini C, Kato T. Sleep Bruxism. In: Principles and Practice of Sleep Medicine. 4th ed. Kryger MH, Roth T, Dement WC, eds. Philadelphia: Elsevier Saunders, 2005: 946-959.

2 ) Moayyedi P, Talley NJ. Gastro-oesophageal reflux disease. Lancet 2006; 367: 2086-2100.

3 ) Miyawaki S, Tanimoto Y, Araki Y et al. Association between noctuanal bruxism and gastoroephageal reflux. Sleep 2003; 26: 888-892.

4 ) Ohmure H, Oikawa K, Kanematsu K et al. Influence of experimental esophageal acidification on sleep bruxism: a randomized trial. J Dent Res 2011; 90: 665-671.

5 ) Mengatto CM, Dalberto Cda S, Scheeren B et al. Association between sleep bruxism and gastoroephageal reflux disease. J Prosthet Dent 2013; 110: 349-355.

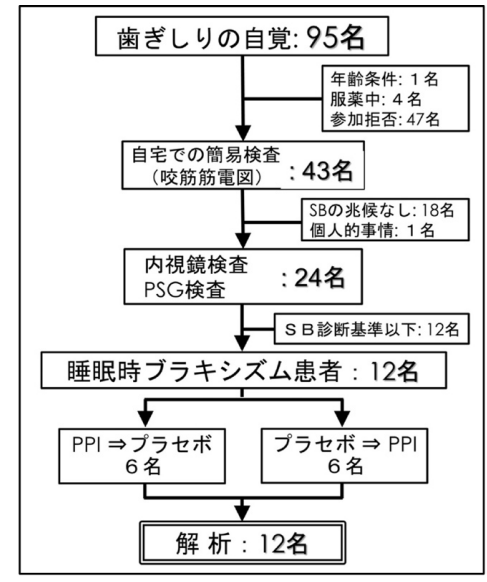

図 実験の流れ

\begin{tabular}{|c|c|c|c|}
\hline & プラセボ群 & PPI 群 & $\mathrm{P}$ 值 \\
\hline \multicolumn{4}{|l|}{ 睡眠関連項目 } \\
\hline 睡眠時間(分) & $351.3(28.0)$ & $350.6(37.7)$ & 0.951 \\
\hline 睡眠効率(\%) & $97.6(1.7)$ & $95.7(6.6)$ & 0.374 \\
\hline \multicolumn{4}{|l|}{ 各睡眠段階の割合 (\%) } \\
\hline NREM1 1 & $19.1(14.0)$ & $22.2(11.3)$ & 0.050 \\
\hline NREM2 & $48.3(11.6)$ & $47.4(9.3)$ & 0.683 \\
\hline NREM3 & $7.5(7.8)$ & $7.1(7.5)$ & 0.811 \\
\hline REM & $16.4(4.1)$ & $14.3(3.6)$ & 0.147 \\
\hline 微小覚醒の頻度 (回/時) & $23.1(11.9)$ & $27.0(18.0)$ & 0.091 \\
\hline 覚醒の頻度 (回/時) & $6.0(1.7)$ & $6.6(4.0)$ & 0.594 \\
\hline \multicolumn{4}{|l|}{ ブラキシズム関連項目 } \\
\hline 筋電図バーストの頻度 (回/時) & $59.4(30.5)$ & $45.7(36.5)$ & 0.021 \\
\hline 咬筋の総活動量 $\left(\times 10^{3}\right.$.\%·s $)$ & $18.3(14.0)$ & $11.7(8.9)$ & 0.016 \\
\hline RMMA の頻度 (回/時) & $6.3(3.1)$ & $4.8(3.8)$ & 0.050 \\
\hline
\end{tabular}

データは平均 (標準偏差), NREM: non rapid eye movement, REM : rapid eye movement

被験者 1 名の PPI 投与時の眼電図データが不良であったため解析 から除外した。

\begin{tabular}{|c|c|c|c|}
\hline & プラセボ群 & PPI 群 & $\mathrm{P}$ 值 \\
\hline \multicolumn{4}{|l|}{ 睡眠関連項目 } \\
\hline 睡眠時間 (分) & $349.3(25.3)$ & $365.0(19.8)$ & 0.074 \\
\hline 睡眠効率 (\%) & $96.6(5.3)$ & $97.4(3.1)$ & 0.347 \\
\hline \multicolumn{4}{|l|}{ 各睡眠段階の割合(\%) } \\
\hline NREM1 1 & $17.1(9.3)$ & $18.2(9.7)$ & 0.448 \\
\hline NREM2 & $45.6(8.5)$ & $46.8(6.8)$ & 0.498 \\
\hline NREM3 & $10.8(9.8)$ & $10.2(9.0)$ & 0.646 \\
\hline REM & $18.1(4.8)$ & $17.0(5.3)$ & 0.436 \\
\hline 微小賞醒の頻度 (回/時) & $23.7(10.9)$ & $23.4(12.0)$ & 0.272 \\
\hline 覚醒の頻度 (回/時) & $5.4(1.7)$ & $5.9(2.3)$ & 0.829 \\
\hline \multicolumn{4}{|l|}{ ブラキシズム関連項目 } \\
\hline 筋電図バーストの頻度 (回/時) & $59.7(33.1)$ & $46.0(21.7)$ & 0.026 \\
\hline 咬筋の総活動量 $\left(\times 10^{3} \cdot \% \cdot \mathrm{s}\right)$ & $19.9(20.4)$ & $13.7(10.6)$ & 0.084 \\
\hline RMMA の頻度 (回/時) & $6.1(3.3)$ & $4.8(2.3)$ & 0.012 \\
\hline
\end{tabular}

デー夕は全て平均 (標準偏差), NREM : non rapid eye movement, REM : rapid eye movement 